\title{
Approaches and Activities Adopted by M. Ed. Student Teachers of English to Teach Reading: A Critical Assessment
}

\author{
Bal Ram Adhikari \\ Department of English Education, Tribhuvan University, Mahendra Ratna Campus, Tahachal, Kathmandu, Nepal \\ Kamal Kumar Poudel \\ Department of English Education, Tribhuvan University, Mahendra Ratna Campus, Tahachal, Kathmandu, Nepal
}

\begin{abstract}
Literature on second language reading suggests that the effectiveness of teaching reading depends largely on theoretically-guided and contextually-informed classroom methodology. In this study, we investigated the classroom methodology adopted by the students of Master of Education (M. Ed.) specializing in English from Mahendra Ratna Campus, Tahachal, who were teaching Bachelor of Education (B. Ed.) reading courses during their practice teaching-hence defined as 'student teachers' (STs). Foregrounding the role of reading in the overall language development and academic achievement of English as a foreign language (EFL) students, the present B. Ed. English curriculum under Tribhuvan University has adopted a content-based approach to teaching reading. In order to understand how those reading courses were taught, we purposively selected ten M.Ed. STs and observed two classes of each, employing a semi-structured classroom observation scheme. In order to cross-compare STs' classroom performance with their theoretical knowledge about reading pedagogy and overall objectives of the reading courses, we also analyzed the English language teaching course the STs had studied in the M.Ed. program as well as B. Ed. reading courses and coursebooks they were teaching. The collected data were coded and analyzed thematically. The findings show that the teaching methodology adopted by the STs goes counter to the principles of ESL/EFL reading and expectations articulated in the reading courses. These findings illustrate the urgent need to reassess the methodology of teaching reading at the tertiary level and minimize the gap between the M. Ed. English students' pedagogical knowledge and their classroom performance.
\end{abstract}

Index Terms-classroom methodology, student-centeredness, student teacher, text explanation, text exploration

\section{INTRODUCTION}

Despite being conventionally recognized as the third skill in "the 'natural order' of skill acquisition" (Larsen-Freeman \& Anderson, 2011, p.44), reading is the primary and most prioritized skill in the educational setting. It is the skill that calls for formal instruction not only in the second language but also in the first language teaching contexts. The centrality of reading in balanced language development as well as overall academic achievement of students has been well documented in second language research (e.g. Grabe, 2002; Carrell \& Grabe, 2002; Richards \& Renandya, 2010; Rai 2015; Chaudhry \& Al-Adwani, 2019). So much is obvious that the ability to read in English is a pivotal skill required of ESL/EFL learners to have a wider access to knowledge and to educate themselves on their own, beyond the instructional setting. Reading is of crucial importance particularly in the ESL/EFL academic context where students have a limited access to an adequate amount of authentic spoken text. In this respect, based on the survey with university teachers and English language teacher trainers, Rai concludes that it is through reading that "the majority of students in Asian countries learn English in schools" (2015, p. 39). Rai further notes that listening and speaking, the skills overrated by the mainstream communicative approach, are rarely taught and assessed in the educational setting of these countries. In the context of Nepal, where English is taught as a foreign language, students encounter with written texts earlier and far more frequently than with spoken texts. The cursory survey of the English curricula of school and university in Nepal also attests Rai's conclusion regarding the pivotal position of reading in the Nepalese context. The secondary level English, which is a compulsory course, for instance, has allocated the highest weightage to reading (40\%) followed by writing (35\%), with listening and speaking bearing the least importance i.e. $10 \%$ and $15 \%$ respectively (Curriculum Development Center, 2014). Reading gets a more prominent position in the university English curricula in Nepal, both as the compulsory subject and a specialization subject (popularly called 'major English'), the latter being the focus of this study.

The university English curricula in Nepal, particularly the specialization courses, have adopted the reading-based approach to teaching English. It means reading has been employed as the basis of developing English proficiency along with content knowledge. It is assumed that reading feeds and extends the other skills. Reading has thus been prioritized 
so as to enrich students' vocabulary, develop their grammar awareness, expose them to textual resources, enrich their content knowledge, fire their imagination and help them to build their own worldviews.

Realizing the contribution of reading to students' overall academic achievement, Faculty of Education under Tribhuvan University revamped the long-existing B. Ed. English curriculum in 2011 with a view to incorporating additional reading courses for prospective secondary level English teachers. It was a policy level intervention to address the growing concern regarding the paucity of the English input that the prospective English teachers suffered due to a limited exposure to reading texts. The subject committee transcended the traditional linguistics-based model of curriculum that treated language mainly as a system to be taught and learned as discrete items and embraced the content-based model that treated language as "discourse and ideology" (Kumaravadivelu, 2006, p. 4), "art" (Kelly,1994, p.4681) and expression. With the curricular modification were initially introduced such courses as Expanding Horizons in English (B. Ed. 2nd year) and Reading, Writing and Critical Thinking (B. Ed. 1st year), and later another reading course was added, namely Critical Readings in English (B. Ed. 3rd year) in 2017. These courses follow the contentbased approach, which can be conceived as the knowledge-enriching model of communicative competence. Diverse in the selection of reading materials in terms of content areas such as language, culture and philosophy; science and technology; and sports and entertainment, each course has organized reading materials thematically with its principal aim to integrate language and content through reading performance. The integration of reading and writing is the common thread that runs through all these reading courses. The reading dimension requires the students to process linguistic resources and content of the text, while the writing dimension requires them to manipulate the resources and content to produce their own texts. To be more specific, the overarching goals of these courses, among others, are to: a) enrich students' vocabulary through exposure to authentic written texts; b) foster critical thinking; c) train students in reading and writing strategies through intensive reading activities in the classroom so that they can transfer them to outof-classroom reading and writing; d) foster simultaneous acquisition of English and subject matter knowledge; and e) integrate language skills and language aspects (Adhikari, 2013, p.25). In principle, these reading courses are underpinned by the theoretical assumption that reading is an interactive, purposive and critical process, and that reading proficiency calls for an extensive reading habit (Hedge, 2000).

Given the centrality of reading in ESL/EFL students' language proficiency and overall educational achievement, it is necessary that we raise questions as to how reading is taught in the classroom. Furthermore, the efficacy of courses, to a great extent, depends on how the aspirations articulated in the courses are actualized in the classroom in the form of pedagogical intervention or mediation. Otherwise stated, a pedagogical intervention is instrumental in achieving course objectives. It is, therefore, important to consider how these reading courses are being taught in the classroom. In this respect, the present study posed the following questions: a) How are reading courses being taught? b) Is the classroom methodology informed by principles derived from L2 reading research and congruent with course expectations? In our attempt to answer these questions, we briefly review the relevant literature on teaching reading principles, and teaching reading approaches and activities. Then, we outline the methodology adopted to carry out the study. After that, we present the findings under three broad themes followed by discussion. Finally, we conclude with the summary of the key findings and a recommendation for further research.

\section{LITERATURE REVIEW}

This section is devoted to the review of literature pertinent to the nature of reading, and the major teaching reading approaches and activities.

\section{A. Nature of Reading}

Reading is not only a pivotal skill but also a complex one to get mastery over. In this respect, Carrell and Grabe (2002) note that "the development of fluent reading abilities by L2 students is a challenging undertaking" (p.233). The complexity embedded in reading is highlighted by the fact that more than the process of extracting information from the written text, it is a complex composite of a number of sub-skills such as "literal comprehension, inferential comprehension, interpreting a writer's purpose, attitude, or tone, following the structure of the passage" (Sadoski, 2005, p.103). The complexity in teaching reading is compounded by several theoretical dilemmas, which among others, arehow to devise effective reading instruction for varied ESL/EFL contexts, how to integrate text structure awareness as a consistent component of reading instruction, and how to recognize extensive reading as an integral part and natural extension of classroom reading (Grabe, 2010). Grabe avers that these are such dilemmas which, particularly in the context of teaching L2 reading, are yet to be adequately dealt with by second language reading research. Another factor that has rendered teaching reading more complicated is the conventional categorization and a widespread acceptance of reading as a receptive skill in contrast with writing as a productive skill which has adversely influenced reading pedagogy, eclipsing its productive dimension and limiting the reader's role as a passive recipient of information served in the text. Challenging such a pedagogically unhealthy and unhelpful dichotomy, second language research recognizes reading as an interactive, purposeful, reflective and critical processes (Hedge, 2000). These processes imply that the reader is an active agent who enters the text with a specific purpose; activates his/her schematic and language knowledge while making sense of the text, constantly reflects on what is given in the text and relates it to his/her experiences, and agrees or disagrees with the writer's stance. In the academic context, reading is almost always 
accompanied by productive activities such as text coding, note-taking, and summarizing. The fundamental question that arises at this point of discussion is how to teach reading effectively to maximize the reader-text interaction.

\section{B. Approaches to and Activities of Teaching Reading}

As far as the methodology of teaching reading is concerned, it is hard to be prescriptive in favor of one at the cost of another because the way that a particular teacher teaches in a particular context is subject to such myriad factors as the teacher's beliefs in, and awareness of, what constitutes teaching reading, the level and age of students, their educational backgrounds and expectations, and educational and social contexts. Each teacher has latitude to choose the methodology that best fits the teaching-learning context. However, the choice is supposed to be guided by principles of language learning and teaching and informed by contextual realities. In this respect, Williams (1986) suggests ten principles for teaching reading and some of which are: a) The primary activity of a reading lesson should be learners reading texts - not listening to the teacher; b) Classroom procedure should reflect the purposeful, task-based, interactive nature of real reading; c) Teachers must learn to be quiet: all too often, teachers interfere with and so impede their learners' reading development by being too dominant and by talking too much; and d) A reader contributes meaning to a text (pp.42-44). Likewise, drawing on the teaching principles postulated by Brown (1994) and the macro-strategies or general plans for language teachers suggested by Kumaravadivelu (2006), we can postulate that teaching reading should prioritize meaning and fluency while taking care of accuracy, foster negotiated interaction between text and reader and among readers themselves, motivate readers intrinsically and prompt them to invest time, effort and attention, boost up their confidence in reading the unknown text and encourage them to take risk while interpreting and producing the text, contextualize the linguistic input, integrate the reading skill into the other skills, raise cultural awareness, and minimize perceptual mismatches.

The reading instruction informed by all or some of the aforementioned principles or strategies can be termed as "a reader-centered approach [...] which focuses on what the reader brings to reading in schematic world knowledge and language knowledge and, second, on their ability and willingness to draw on productive strategies in the course of reading" (Wallace, 2001, p.26). The reader centered-approach is guided by the constructivist assumption that learners are active determiners of learning and they "shape the process of learning in powerful ways" (Richards, 2001, p.214). Obverse of the transmission-oriented approach that views learners as the passive conduit through which the input passes, the reader-centered approach conceives learners as input processors and invites their active participation in order to explore the text by themselves under the judicious guidance of the teacher. Distinguishing between traditional reading pedagogy and the reader-centered approach, Wallace (2001) notes that the former is a product-oriented one in which the teacher presents the text and prompts students to carry out post-reading tasks, whereas the latter is a process-oriented one that engages students in pre-reading tasks such as brain-storming, semantic mapping, or agreeing-disagreeing so as to activate and capitalize on their existing knowledge before the actual text-reader interaction takes place. Wallace's (2001) distinction partly echoes Hamp-Lyons and Proulx's (1982) comparison of two methods of teaching advanced ESL reading, termed as a traditional method and a skills-based/discourse analysis method. To reference Hamp-Lyons and Proulx (1982), the traditional method of teaching reading is product-centered, and so regards reading as a passive (receptive) skill, ignoring readers' schema. This approach requires readers to decode the text for 'right' answers, and commonly practices reading aloud by the teacher and/or students. Likewise, students approach the reading text mostly individually, and the teacher is the authority in the classroom who is expected to supply explanation of the text and answers to reading questions. On the contrary, the skills-based method is process-centered, and thus regards reading as an active, interpretive and communicative process of generating meaning from the text. With a due focus on meaning, this method values the activation of readers' schemas and affective domains, assesses their comprehension by means of a variety of questions, and encourages them to manipulate content, language and textual resources to produce their own texts. Students are engaged in silent reading, and collaboration among themselves is highly encouraged. The teacher's role is to facilitate the reading process rather than to explain the text and supply readers with answers. Although proposed almost four decades ago, Hamp-Lyons and Proulx's (1982) skills-based approach still holds true for and is of high relevance to contemporary ESL/EFL reading pedagogy, as it regards students as the point of reference and prizes text exploration by students themselves over text explanation by the teacher. Moreover, it acknowledges the role of collaboration among readers and integration of reading into other skills.

Ren and Wang (2018) propose the production-driven approach to teaching reading with a view to reforming tertiary English reading instruction in China in which they observe that the traditional teaching method dominates Chinese reading classes. Usually reading instructors adopt the read-and-answer approach which is accompanied by "explanation of key words and phrases as well as long and complex sentences", failing to "stimulate students' interest in reading" (Ren \& Wang, p.13). This production-driven approach to teaching reading is the application of production-oriented approach to teaching English to university students in China advanced by Wen (2016). The approach advocates the principles of learning-centeredness instead of learner-centeredness, the integration of language learning and language use and whole-person education. Furthermore, the approach is underpinned by the output-driven hypothesis, the selective learning hypothesis and the input-enabling hypothesis. These principles and hypotheses are actualized in the classroom by means of three phases of the teaching process that entail motivating, enabling and assessing (see Wen 2016). Ren and Wang (2018) apply these principles, hypotheses and teaching processes to second language reading instruction, which not only disrupts the dichotomous view of receptive and productive skills but also conceives reading 
as a process of generating meanings. The meanings thus generated are to be externalized by means of productive activities such as "speaking, writing, translation and interpreting" (Wen, 2016). The crux of the production-driven approach is that input activities should be seamlessly integrated into output activities.

Instruction that conceives reading as a process, recognizes the active participation of students and emphasizes the integration of reading into other skills tends to guide the students through different phases of reading. In this regard, Hedge (2000) observes that a three-phase procedure has been a standard practice of contemporary reading instruction. The three-phase procedure is termed differently such as pre-reading, while-reading, and post-reading (Wallace, 2001; Hedge, 2000; Lazar, 2009), anticipation, building knowledge and consolidation (Crawford, Saul, Mathews \& Makinster, 2005), engage, study and activate (Harmer, 2007), and motivating, enabling and assessing (Wen, 2016). The ultimate intention of guiding readers through these phases is to help them:

develop increasing ability to tackle texts. This is in contrast to more traditional materials in which reading would be 'tested' through a procedure in which learners would read a text with or without introduction, possibly with some pre-teaching of vocabulary, and they would be required to answer comprehension questions. (Hedge, 2000, p.209)

The organization of reading tasks into three phases is guided by the notion that reader-text interaction takes place with different purposes with varying degrees of intensity at different phases. It underscores the necessity of preparing readers by activating their experiences, knowledge and language resources before they enter into and interact with the text and of taking them beyond the text through production activities.

The present study is guided by the pedagogic precept that methodology, i.e. what teachers actually do in the classroom in order to achieve the stated or unstated objectives (Kumaravadivelu, 2006, p. 84) has a decisive role to play in addressing the reading complexities discussed above and maximizing the reader-text interaction. With this assumption in mind, the present study aimed at exploring the practice of teaching reading adopted by M.Ed. student teachers to teach the reading courses prescribed for B. Ed. specialization in English. To this end, we draw on the constructs underlying the reader-centered approach, the skills-based method and the production-driven approach discussed above as the theoretical lenses.

\section{MethODOLOGY}

The present study followed a qualitative research design to explore the teaching methodology adopted by M. Ed. student teachers with English specialization while teaching the reading courses to B. Ed. students of English. The data were collected by means of a semi-structured observation strategy that combined the broadly identified observational categories such as approach, activities and mode of interaction with narrative field notes and reflections (Dornyei, 2007; Nunan 2010; Riazi, 2016). The observational categories used in the scheme draw partly on the Communicative Orientation of Language Teaching (Nunan, 2010) and partly on our own experience as teacher educators and teaching practice supervisors. The participants comprised the English students in the final year of the M. Ed. program from Mahendra Ratna Campus, Tahachal, Tribhuvan University, who were sent to different higher secondary schools, or campuses in Kathmandu with B. Ed. programs in English. Altogether ten student teachers teaching B.Ed. reading courses were selected purposively and two lessons of each teacher were observed. One of the reasons for selecting the M.Ed. student teachers was that these were the prospective college teachers who had studied and passed the course Advanced English Language Teaching Methodology (Eng. 591), which, apart from acquainting them with general principles, approaches, methods and techniques of teaching English in general, exposes them to contemporary ELT reading pedagogy underpinned by principles of reader-centeredness, learning-centeredness, the contextualization and extension of reading input, and the integration of reading into other skills. As teacher educators, we wanted to explore how these theoretically-equipped prospective teachers would teach reading in the actual classroom setting.

During the observation we assumed ourselves carrying out the dual role as internal supervisors and researchers. The former was the primary role assigned to each of us by the campus administration to observe the student teachers' classes and provide them with constructive feedback in order to prepare them for the final observation by the external supervisor. As a researcher, each of us recorded their classroom performance in the semi-structured observation scheme accompanied by notes and reflections. To ensure the anonymity of the participants, the participants were de-identified as ST1, ST2,... and ST 10. We adopted the priori coding scheme which, according to Riazi, "is usually developed on the basis of theoretical backgrounds related to the research problem, as well as the analysis of a small portion of the collected data" (2016, p.255). The assignment of the segments of the data to the appropriate code in the coding scheme was followed by annotations and memos, on the basis of which the broader themes were generated. To cross-compare their teaching with the pedagogical knowledge they had acquired in the Master's program and with the expectations of the reading courses they were teaching, we also analyzed the English language teaching (ELT) course they had studied at the Master's level, and the reading courses and coursebooks they were teaching.

\section{RESULTS AND INTERPRETATION}

Considering the overall data collection design and the nature of the actual data, the results are presented under the three thematic headings generated around and across the observational categories: 'text-explanation at the cost of text- 
exploration', 'devaluation of activation and extension phases of teaching reading', and 'incongruence between pedagogical knowledge, course expectations and classroom performance'.

\section{A. Text Explanation at the Cost of Text Exploration}

The explanation of reading texts by student teachers (STs) dominated all the classes which we observed, pushing to the periphery the exploration of texts by the students themselves as a tendency. Put differently, the STs explained the text to their students requiring them to take notes rather than engaging them in reading activities to explore the text themselves. Explanation was often accompanied by a few oral questions and always followed by some written questions so as to check the Ss' textual comprehension. Let us take the case of ST10, for instance. While teaching the topic 'The teacher who changed my life' from the book New Direction: Reading, Writing and Critical Thinking (Gardner, 2009), ST10, in his attempt to initiate the whole-class discussion, began the lesson with a personalizing question - 'Do you remember a teacher who has changed your life?' As no answer came from the class, the ST introduced the writer and presented on a chart paper a list of roles and/or traits of a good teacher extracted from the text and lectured on each point elaborately. The class listened to the explanation almost passively ('pin-drop silence' in the traditional concept of 'good classroom management'!), while some students took notes occasionally. It was a whole-class teaching mode with very little interaction between teacher and students with almost no interaction between the students working in pairs or groups. The ST's lengthy explanation was followed by comprehension-checking questions which the students had to answer in the written form individually. Some further evidence of dominance of explanation over exploration comes from ST8, who, while teaching the topic 'The eyes of the tiger' from the book Readings for the New Horizons (Awasthi, Bhattarai \& Rai, 2016), started the lesson by showing a picture of a tiger and posing two questions to the class about it. After listening to some of the students' responses, the he explained different types of essay, and presented the theme of the essay orally. The explanation of the text was followed by the distribution of handouts that contained the summary and some comprehension-checking questions. Rather than inviting and acknowledging multiple responses from the students, the ST dictated answers to them. Despite the nominal presence of pre-reading activities (or better call preexplanation activities!), this class, like the others, was inordinately explanation-oriented, depriving the students of opportunities to interact with the actual text.

All in all, the foci of the explanation were the topic, background of the author, gist of the text, plot, characters and theme (in the case of a story) and line-by-line interpretation (in the case of a poem). The STs explained either directly from the book or used the text-based points they had prepared beforehand on the chart paper. This tendency stands counter to the teaching suggestion given in the teachers' manual of the course being taught, which clearly suggests teachers that "It is NOT your job to give them a summary [...]. Your job is to provide a forum in which they CAN get meaning, and to scaffold the lessons so they can do it on their own" (Law, 2012, p. iv, emphasis in original).

The irony of these teachers' inordinate inclination to the explanatory approach followed in the reading class was that the students were listening to the text rather than reading it. That is, reading was eclipsed by listening followed by nominal speaking and writing activities. Consequently, even basic reading activities were virtually absent and it was hard to say whether the aim of their teaching was to enhance the students' listening comprehension or reading comprehension.

\section{B. Devaluation of Activation and Extension Phases of Teaching Reading}

Fifteen lessons made use of activation activities. The rest of the lessons began without any preparatory activities, that is, the teachers wrote the titles on the board and explained the texts elaborately. Table 1 summarizes the types of activities being used before exposing the reading text to the students:

TABLE 1

ACtivation ACtivitiEs USED BEFORE TEXT PRESENTATION

\begin{tabular}{l|l} 
Activation Activities & No. of Lessons \\
\hline Revision of previous lesson & 13 \\
Topic-related questions & 8 \\
Picture-related questions & 4 \\
Contextualization/Personalization questions & 3 \\
Information about the writer/topic & 4
\end{tabular}

The types of pre-reading (or pre-explanation) activities and their frequency in the fifteen lessons display somehow observable patterns (Table 1). A very brief revision of the previous lesson by asking few questions to the whole class was found to be the most commonly preferred way of preparing the students for the lesson, whereas contextualizing and personalizing the topic by posing such questions as - 'Do you know how many tigers there are in Nepal?' 'Have you ever seen a tiger in the jungle?' 'Do you remember a teacher who has changed your life?' etc. were the least preferred ones. In 12 of the observed lessons, the STs invited the students to make some speculation about the theme by posing the questions related to the topics or the pictures. Four of the lessons began with some background information about the writer or an elaboration of the topic.

There is no total denying that these activities were instrumental in instigating some interaction in the class by triggering the students' inner resources. However, the activities suffered two major limitations. First, they were almost exclusively limited to the interaction between teacher and the whole class or the responses from the teacher-selected 
students rather than between or among students working in pairs or groups. The second limitation concerns the efficacy of such activities because they failed to invite the students to an open interaction about the topic. In some cases, there were no responses from the class at all. Another aspect noted during the observation was that none of the STs used the pre-reading activities recommended in the coursebooks such as New Directions: Reading, Writing and Critical Thinking (Gardener, 2009). The activities such as journal writing, agreeing and disagreeing, brainstorming, free writing, clustering, and journalistic questions given in the book were left untouched by the STs. The purpose of these activities is to encourage the students to express their personal opinions and experiences, and compare their responses with those of the others.

Unlike the activation activities, the post-reading (or post-explanation) activities were perceived as the obligatory part of teaching and, hence, were more prioritized. The STs' elaborate explanation. and sometimes the students' reading of the given summary or notes were followed by some writing activities such as answering long answer questions, summarizing the text and essay writing. Each lesson constituted a combination of at least two activities after text explanation from the ST or some reading carried out by the students. Table 2 presents the types of such writing tasks.

TABLE 2

EXTENSION ACTIVITIES USED AFTER EXPOSING STUDENTS To TEXTS

\begin{tabular}{l|l} 
Extension Activities & No. of Lessons \\
\hline Long question answers & 20 \\
Summary writing & 15 \\
Paragraph writing & 13 \\
Essay writing & 10
\end{tabular}

Answering the questions, as Table 2 shows, took place in all the lessons. The ST, after explaining the text or presenting its summary or points to the class, required the students to answer some of the questions given at the end of the passage either in the form of classwork or home assignment. The rest of the activities -summary writing, paragraph writing and essay writing- were assigned as homework.

\section{Incongruence between Pedagogical Knowledge, Course Expectations and Classroom Performance}

The analysis of the advanced ELT course that the STs had studied reveals that the course exposed them to theoretically grounded, contextually-informed and SLA research-supported methods of teaching reading which underscored the processes of second language reading, a necessity of activating readers' inner resources and framework for teaching reading (Hedge,2000; Wallace, 2001; Harmer, 2007), teaching strategic reading (Janzen, 2010), and issues in teaching reading (Carrell \& Grabe 2002; Grabe, 2010). The analysis further reveals that the reading component of the course valued reading as an interactive and creative process (Hedge, 2000), recognized students as meaning-generating agents and instructed the teachers to guide their students through different phases of reading. However, the teachers seem to have failed to translate these theoretical insights into teaching reading in their workplace, i.e. the actual classroom situation. In other words, the absence of student-centeredness, a limited interaction between text and students, the nominal use of the activation activities, the explanation of the text as a final product, and almost absence of whilereading activities all evidence incongruence between their pedagogical knowledge and classroom methodology.

A cross-comparison of the STs' classroom performance with the overall aim of the reading courses, the teaching guidelines given in the coursebooks and teachers' manuals evidence further incongruence between course expectations and classroom methodology.

Contrary to the objectives of the reading courses (for example, to enrich students' academic vocabulary through reading, foster critical reading through active student participation, train students in strategic reading and integrate reading into writing), the vocabulary activity was completely neglected; critical reading was pushed to the periphery; the suggested reading strategies were virtually absent and the integration of reading with writing and speaking was kept to a minimum. Likewise, the suggestions from the coursebook editors and teachers' manuals (such as that the teacher should assume the role of a supporter and each lesson should be structured into three broad phases) did not seem to have found their adequate space in the reading classes which were observed.

\section{Discussion}

The study aimed at exploring the classroom methodology adopted by the M.Ed. student teachers (STs) while teaching reading to $\mathrm{B}$. Ed. students. The analysis of the data reveals the teachers' adoption of the traditional method of teaching reading. Notably, their teaching showed poor congruence with the principles of teaching reading and the course expectations.

The STs' undue inclination to the explanatory approach minimized text-reader interaction, discounted the students' desire and ability to generate their own meanings from the text and imposed the STs' monological meanings on them. The explanation also disregarded the fact that each text is characterized by what Bakhtin (1981) calls "polyglossa" (Adams, 1992, p.838), and reading is a dialogic process of constructing meanings from this polyglossic entity. Moreover, the STs showed little sign of acknowledging the fact that the text at the advanced level should be "actively interpreted" (Pym, 2014, p.99) by students themselves rather them explained to them. The marginalization of text exploration by readers themselves and the adoption of the meaning-transmission approach both have a detrimental 
effect on student motivation and involvement. The demotivation and passivity of the students, for instance, were overtly visible in almost all the observed classes.

The STs' fascination with the explanatory approach can also be discussed from the perspective of their role in the reading class. Assuming their centrality to the teaching reading process, these teachers showed their unwillingness to shun the traditional role as an authority. Put differently, each ST presented himself/herself as an interpreter of language and content of the text, content supplier, content controller, and evaluator. The role they assumed was found to be in conflict with Williams' rule of thumb that "the teacher's role is [...] less that of information-giver/text-explainer, and more that of coach/classroom organizer/trouble-shooter/consultant/personnel manager/catalyst. This latter role is a far more professional one (and far more demanding!) than that of straightforward text-explainer" (1986, p.44). Due to the STs' unwillingness or inability to abandon the center stage in the class, their teaching suffered "hegemonic univocality" (Vieira, 2002, p. 95), depriving the students of opportunities to participate in reading-oriented and reading-generated activities. Their teaching exhibited the defining tenets of the traditional method of teaching reading (Hamp-Lyons \& Proulx, 1982; Wallace, 2001) and echoed Ren and Wang's (2018) finding about teaching reading in Chinese universities that "up till now many instructors employ the traditional teaching method, which fails to stimulate students' interest in reading" (p.13). This finding about the teaching method is also in consistent with that of Poudel and Sharma (2019) who reported the use of the excessive lecture in English language teaching in higher education in Nepal.

Regarding the reading process, the use of activation activities was conceived either redundant to or burden on the readers, whereas the use of extension activities was kept to a minimum. Accordingly, the activation of students' "schematic knowledge and language knowledge", to use Hedge's (2000) terms, before presenting the text, and the extension of the students' knowledge after the presentation were either totally ignored or least prioritized in all the lessons. Put simply, pre-reading and post-reading phases were of secondary importance to the STs despite the fact that the contribution of these phases to students' reading proficiency has been theoretically recognized and empirically justified (e.g. Grabe, 2002) and therefore are pedagogically recommended (e.g. Hedge, 2000; Harmer, 2007). In principle, these phases are treated as integral parts of the teaching reading procedure. In practice, however, the students were not adequately prepared for reading by activating their existing language and knowledge resources. Nor were they satisfactorily engaged in post-reading or post-explanation activities to take them beyond the text and integrate reading into the production skills i.e. speaking and writing.

As to the use of extension activities, having the students write the summary of the text stood out ineffective because the teachers had already explained the passage and summarized it for the class or presented its theme in points. Consequently, the summarizing task did not require the students to read the passage again. Obviously, they would simply rewrite what was served to them, or summarize the passage with the help of the teacher-supplied points. Compared to summarizing, writing a paragraph can be considered more productive and effective. Since the task necessitated the students to go beyond the teacher-supplied summary or points and read the passage themselves as well as add some information from their own sides. Finally, more productive, integrative and liberating than summarizing or paragraph writing would be essay writing, though least prioritized by the STs. To produce their own texts, the students needed to consult outside resources apart from making use of the ST-supplied information and reading the given passage.

The activities used in the extension phase of teaching lacked variety. Furthermore, those activities were not effective enough to lead the students beyond the comprehension phase by engaging them in the analysis of the language and content of the passage on the one hand and by challenging them to critically evaluate the text on the other. This phase failed to incorporate text-related activities that provoke students into reflecting on the theme of the passage, sharing their opinions in pairs/groups, agreeing or disagreeing with the writer's stance, identifying with the writer or characters, and creating a parallel text-all desirable activities in an advanced reading classroom.

As their instructors as well as supervisors, we were anticipating that teaching reading by these trainee teachers would be informed at the very least by the theoretical knowledge they had gained from the course. Contrary to our anticipation, there was conspicuous incongruence between how they were taught to teach reading and how they were teaching reading to their students. Obverse of the constructivist spirit of the course that treats students as meaninggenerating and meaning-constructing agents, the STs were heavily guided by the behavioristic approach that conceives students as passive recipients of the information supplied by the teacher. This type of theory-praxis gap, however, is not limited to STs alone. A number of studies (e.g. Karn, 2006; Richards, 2008; Adhikari, 2017) have reported that even practicing or experienced teachers fail "to apply such knowledge (knowledge about language and language learning) in their own teaching" (Richards, 2008, p.5). Concerning the gap, Karn (2006) has a similar conclusion to make, "It is very unfortunate that the theoretical knowledge obtained from ELT courses is not put into practice during actual teaching" (p.77). The gap suggests the lack of the conversion of declarative knowledge about teaching reading into procedural knowledge. Furthermore, incongruence between the course expectations and the actual classroom performance indicates the teachers' insufficient familiarity with the nature of the reading courses they were teaching.

These findings are significant because they point to an urgency of reassessment of teaching reading at the tertiary level. In order for ESL/EFL teaching reading to be effective, it should be well informed by the principles of teaching in general and those of teaching reading in particular, and recognize and capitalize on the readers' inner resources and prioritize reader-text interaction. Another aspect implicated in the findings is that the teacher training program should 
be in the direction of minimizing the gap between the pedagogical knowledge of the student teachers (M. Ed. students of the advanced reading courses) and their actual classroom performance.

The study involved some limitations. Since the participants were student teachers, it is hard to claim that these findings can be generalized to in-service university teachers teaching reading courses. Moreover, the study exclusively concerned the how-aspect of teaching reading at the tertiary level, the why-aspect has remained untouched. Teachers' inclination to one particular teaching approach accompanied by particular activities should be studied from their perspectives too so as to uncover their assumptions and beliefs about reading and teaching reading, and contextual realities that shape their teaching.

\section{CONCLUSION}

The study found that the student teachers (STs) failed to adopt the principled approach to teaching reading. Their undue inclination to text explanation at the cost of text exploration, the absence of potentially better while-reading activities and the marginal use of pre- and post-reading activities all lead to the conclusion that their teaching methodology was theoretically ill-informed and pedagogically misguided. Likewise, there was conspicuous incongruence between what the STs had studied in the advanced teaching reading course and how they were actually teaching to the students. Furthermore, incongruence was also noticed between the course expectations and the way the STs carried our teaching reading in the actual classroom situation. This also suggests a need for conducting classroom research into teaching reading at the tertiary level that 'produces' the prospective English teachers.

\section{ACKNOWLEDGEMENTS}

The publication of this article was funded by University Grants Commission (UGC), Nepal. The authors would like to thank UGC for the financial support. They are also thankful to the anonymous reviewers for their constructive feedback.

\section{REFERENCES}

[1] Adams, H. (Ed.). (1992). Critical theory since Plato. New York: Harcourt Brace Jovanovich College Publishers.

[2] Adhikari, B. R. (2013). Advanced reading courses: New aspirations and challenges. Rural Aurora, 2(2), 24-33.

[3] Adhikari, B.R. (2017). Student teachers' views on grammar and grammar teaching, and its communication to their students. Journal of NELTA, 21(1-2), 88-99. doi: 10.3126/nelta.v22i1-2.20044.

[4] Awasthi, J.R., Bhattarai, G.R, \& Rai, V. S. (2016). Readings for the new horizons. Kirtipur: Sunlight Publication.

[5] Brown, D. (1994). Principles of language learning and teaching (3rd ed.). Eaglewood Cliffs NJ: Prentice Hall Regents.

[6] Carrell, P.L., \& Grabe, W. (2002). Reading. In Schmitt, N. (Ed.), An introduction to applied linguistics (pp. 233-250). London: Hodder Education.

[7] Chaudhry, A.S., \& Al-Adwani, A. (2019). Reading practices of EFL students: A survey of Kuwaiti college students. English language teaching, 12(5), 130-144. doi.org/10.5539/elt.v12n5p13.

[8] Crawford, A., Saul, E., Mathews, S., \& Makinster, J. 2005). Teaching and learning strategies for thinking class. Kathmandu: Alliance for Social Dialogue.

[9] Curriculum Development Center (2012). Advanced English Language Teaching Methodology (591). Tribhuvan University: Nepal.

[10] Curriculum Development Center. (2014). Secondary education curriculum (9-10). Retrieved November 10, 2019 from http://cdclibrary.org

[11] Dean's Office (2015). Courses of four year B. Ed. annual system. Kirtipur: Dean's Office, Faculty of Education.

[12] Dornyei, Z. (2007). Research methods in applied linguistics. Oxford: Oxford University Press.

[13] Gardner, P. S. (2009). New directions: Reading, writing, and critical thinking (2nd ed.). Cambridge: Cambridge University Press.

[14] Grabe, W. (2002). Reading in a second language. In R. B. Kaplan (Ed.), The Oxford handbook of applied linguistics (pp. 4959). Oxford: Oxford University Press.

[15] Grabe, W. (2010). Dilemmas for the development of second language reading abilities. In J. C. Richards, \& W.A. Renandya. (Eds.). Methodology in language teaching: An anthology of current practice (pp.287-294) (1st South Asian ed.). India: Cambridge University Press.

[16] Hamp-Lyons, Liz; Proulx, G. (1982). A comparison of two methods of teaching advanced ESL reading. Paper presented at the TESOL Summer Meeting. Retrieved November 1, 2019 from https://eric.ed.gov.

[17] Harmer, J. (2007). The practice of English language teaching (4th ed.). London: Pearson.

[18] Hedge, T. (2000). Teaching and learning in the language classroom. Oxford: Oxford University Press.

[19] Janzen, J. (2010). Teaching strategic reading. In J. C. Richards, \& W.A. Renandya. (Eds.). Methodology in language teaching: An anthology of current practice (pp.287-294) (1st South Asian ed.). India: Cambridge University Press.

[20] Poudel, K. K., \& Sharma, N. P. (2019). "Who Bothers!" A Common Ailment in Higher Education ELT Classrooms in Nepal. English Language Teaching, 12(8), 1-13.

[21] Karn, S.K. (2006). Observations on the effectiveness of ELT courses of Tribhuvan University. Journal of NELTA, 10(1), 75-77. doi:10.3126/nelta.v10i1.3258.

[22] Kelly, L.G. (1994). Translatability: Limits. In R. E. Asher, \& J. M. Y. Simpson (Eds.), The encyclopedia of language and linguistics (pp. 4677-4683). Oxford; New York: Pergamon Press. 
[23] Kumaravadivelu, B. (2006). Understanding language teaching: From method to postmethod. Mahwah, New Jersey: Lawrence Erlbaum Associate, Publishers.

[24] Larsen-Freeman, D. \& Anderson, M. (2011). Teaching \& principles in language teaching. Oxford: Oxford University Press.

[25] Law, B. (Ed.). (2012). Expanding horizons in English: Teachers' manual. Nepal: NELTA.

[26] Lazar, G. (2009). Literature and language teaching (1st Indian ed.). Cambridge: Cambridge University Press.

[27] Nunan, D. (2010). Research methods in language learning (1st South Asian ed.). Cambridge: Cambridge University Press.

[28] Pym, A. (2014). Exploring translation theories (2nd ed.). London and New York: Routledge.

[29] Rai, V. S. (2015). Post-modern ELT: Whose woods are these.... In V.S. Rai, L. Gnawali, B. Luitel, G.P. Panday, B. Adhikari, \& M. Neupane (Eds.). NELTA Conference Proceedings (pp.37-41). Nepal: NELTA.

[30] Ren, J, \& Wang, N. (2018). College English reading instruction in North China Electric Power University: The productiondriven approach. English Language Teaching, (11)10, 10-15. doi.org/10.5539/elt.v11n10p10.

[31] Riazi, A. M. (2016). The Routledge encyclopedia of research methods in applied linguistics. London and New York: Routledge.

[32] Richards, J. C. (2001). Postscript: The ideology of TESOL. In R. Carter \& D. Nunan (Eds.), The Cambridge guide to teaching English to speakers of other languages (pp.213-217). Cambridge: Cambridge University Press.

[33] Richards, J.C. (2008). Growing up with TESOL. English Teaching Forum, 46(1), 2-11.

[34] Richards, J.C., \& Renandya, W. A. (Eds.). (2010). Methodology in language teaching: An anthology of current practice (1st South Asian ed.). India: Cambridge University Press.

[35] Sadoski, M. (2005). Conceptual foundations of teaching reading. New York: The Guilford Press.

[36] Vieira, E. R. P. (2002). Liberating calibans: Readings of antropofagia and Haroldo de Campos' poetics of transcreation. In S. Bassnett \& H. Trivedi (Eds.), Postcolonial translation: Theory and practice (pp.95-113). London and New York: Routledge.

[37] Wallace, C. (2001). Reading. In R. Carter \& D. Nunan (Eds.), The Cambridge guide to teaching English to speakers of other languages (pp.21-27). Cambridge: Cambridge University Press.

[38] Wen, Q. (2016). The production-oriented approach to teaching university students English in China. Language Teaching 1-15. doi.org/10.1017/S026144481600001.

[39] Williams, R. (1986). 'Top ten' principles for teaching reading. ELT Journal (40)1, 42-45. doi:10.1093/elt/40.1.42.

Bal Ram Adhikari, the principal author, is a Lecturer in English Education at Tribhuvan University, Mahendra Ratna Campus, Tahachal, Kathmandu. His areas of research interest include reading pedagogy at the tertiary level and Translation Studies. He has to his credit several published articles in English language teaching and literary translation. At present, he is pursuing a PhD in Translation Studies from Tribhuvan University.

Kamal Kumar Poudel, the corresponding author, is an Associate Professor in English Education, currently working at Tribhuvan University, Mahendra Ratna Campus, Tahachal, Kathmandu. He is particularly involved in teaching Linguistics and Research Methodology courses to post-graduate students of English Education, and has had considerable experience in teacher training and language pedagogy. He has got a number of research articles related to his specialization area published at national and international levels. Currently a Ph.D. scholar under the Faculty of Education, Tribhuvan University, he is researching in the field of functional linguistics. 